$\xi=-1$

\title{
Integrating the BSC and KPI Systems for Improving the Efficiency of Logistic Strategy Implementation in Construction Companies
}

\author{
Volodymyr Gryshko ${ }^{1 *}$, Mykola Zos-Kior ${ }^{2}$, Olena Zerniuk \\ ${ }^{1}$ Poltava National Technical Yuri Kondratyuk University, Ukraine \\ ${ }^{2}$ Poltava National Technical Yuri Kondratyuk University, Ukraine \\ ${ }^{3}$ Poltava National Technical Yuri Kondratyuk University, Ukraine \\ *Corresponding Author E-Mail: Zoskior@Gmail.Com
}

\begin{abstract}
The article presents the theoretical and practical basis of BSC and KPI systems integration with a view to improve the efficiency of logistic strategy implementation at construction enterprises. It has been determined that an information logistic system of a construction company should be based on the system of complex performance indexes of logistic activity and it also should have a corresponding to them logistics information system that reflects the running state of logistic strategy implementation and enables to evaluate its efficiency. The exogenous variables, affecting the indicated efficiency, have also been presented in an entry. Based on the research findings, it has been concluded that the proposed guidepost indicators provide an opportunity to insure the process of logistic activity based on modern approaches and procedures in accordance with the chosen logistics strategy of the construction company.
\end{abstract}

Keywords: balanced scorecard system, construction company management, information decision support, key performance indices, logistic strategy.

\section{Introduction}

Even the most effective solution does not guaranty its effective execution. Logistics strategy of the enterprise, as well as any managerial decision, requires a qualitative performance evaluation, which is based on a set of performance indicators of the enterprise logistics system development. The subset of performance indicators is an integral part of information system effectiveness at the enterprise, which makes it possible to monitor the logistics strategy implementation. Unfortunately, in Ukraine, the underdevelopment of information systems in construction companies regarding logistical expenditure records and cost management is predominantly discernible. Alongside this, there is also no accurate and clear systematization of the indicators system for assessing the results of logistic activities, which in its turn does not allow either to effectively manage logistics costs, logistics system and logistics chains, or to implement effectively the logistics strategy of enterprises. For this reason, at present we consider to be of current interest the formation of an information logistics system of a construction company, which will be based on a system of logistic activity composite indicators, which will reflect the running state of logistics strategy implementation and will allow to evaluate its effectiveness.

\section{Main Body}

The information logistics system of a construction company should be based on the system of logistic activity composite indicators and ought to have a corresponding to them logistics infor- mation system that reflects the running state of logistic strategy implementation and allows to evaluate its efficiency.

\subsection{Dynamics of Investments and Results of Activity of Construction Companies}

For instance, over 2010-2015 years residential fixed investment in Ukraine per capita grew by $79.9 \%$, which in percentage to the total capital investment combines to $16.7 \%$ (Table 1).

Table 1: Capital investment in residential construction

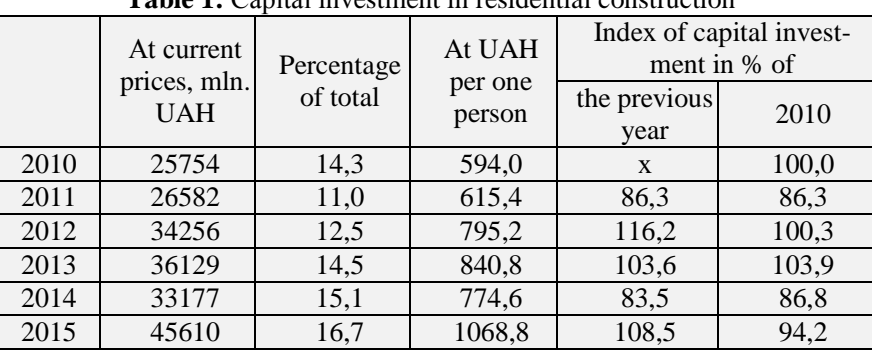

At the same time, over 2010-2016 years the total quantity of built apartments per 1000 inhabitants of the resident population increased by $75 \%$, which, with the inflation rate of $204.9 \%$ over the same period (Table 2), may indicate either an improvement of the efficiency in the industry through the introduction of innovative solutions, related to the resources management and cost management, or the deterioration of the quality of performed work and the housing itself or the reduction of the business profitability.

\footnotetext{
${ }^{1}$ Residential construction in Ukraine, 2010-2015. Statistical publication. Kyiv, 2016. -89 p.
} 
Table 2: Total number of apartments built (units) ${ }^{2}$

\begin{tabular}{|c|c|c|c|c|c|c|}
\hline \multirow{2}{*}{} & \multicolumn{3}{|c|}{ Total } & \multicolumn{2}{c|}{ per 1 000 resident population } \\
\cline { 2 - 3 } & \multirow{2}{*}{$\begin{array}{c}\text { of apart- } \\
\text { ments } \\
\text { built }\end{array}$} & $\begin{array}{c}\text { including } \\
\text { urban } \\
\text { areas }\end{array}$ & $\begin{array}{c}\text { in rural } \\
\text { areas }\end{array}$ & \multirow{2}{*}{$\begin{array}{c}\text { ments } \\
\text { mepart- } \\
\text { built }\end{array}$} & $\begin{array}{c}\text { in } \\
\text { urban } \\
\text { areas }\end{array}$ & $\begin{array}{c}\text { in } \\
\text { rural } \\
\text { areas }\end{array}$ \\
\hline 2010 & 71292 & 52564 & 18728 & 1,6 & 1,8 & 1,4 \\
\hline 2011 & 77330 & 61455 & 15875 & 1,8 & 2,1 & 1,2 \\
\hline 2012 & 83355 & 63115 & 20240 & 1,9 & 2,1 & 1,5 \\
\hline 2013 & 92612 & 67163 & 25449 & 2,2 & 2,3 & 1,9 \\
\hline 2014 & 105241 & 76991 & 28250 & 2,5 & 2,6 & 2,1 \\
\hline 2015 & 120307 & 89076 & 31231 & 2,8 & 3,0 & 2,4 \\
\hline
\end{tabular}

Namely, we can trace an uncertainty about the working efficiency of a construction company, which is difficult to investigate.

\subsection{Exogenous and Endogenous Variables Affecting the Effectiveness of Logistics Strategy Implementation at Construction Enterprises}

Taking the above mentioned into consideration, it is possible to present exogenous variables that influence the indicated efficiency:

construction enterprises, while carrying out their primary activities, spend the funds of population on the housing construction; technological development, improvement of construction technology, and therefore the improvement in the quality of newly-built housing, receive funding from investments in the industry; timely project construction and suitable quality of executed works significantly depend on the material remuneration of workersbuilders, that is, on labour payment expenses. For this reason, the annual payroll is important for all construction companies in a particular industry $[7,9,11,13,14]$. It affords an opportunity to take into account the specific character of construction production, which is associated with a considerable part of the works, which are still performed manually.

Consequently, due to the changes in the volume of investments in construction enterprises from all possible sources, changes in investments of the population in housing construction and changes in the payroll budget $[2,4,8]$, there will be changes in such effective endogenous variables as:

the total floor area of housing accommodations, put into operation over the year;

general housing stock throughout the region;

the financial result of construction companies before tax.

\subsection{Scheme for Implementing the BSC and KPI System}

From theoretical and practical perspectives, a common system of such indicators - "the Balanced Scorecard (BSC)" - has been developed to assess the efficiency of work execution. This management system, developed in early 1990-s by Robert S. Kaplan and David P. Norton, the purpose of which is to provide more precise statement of strategic plans and their implementation, is wider in its intended purpose than the systems that measure only financial figures $[3,5]$. In terms of logistics and logistics strategy implementation, BSC focuses on business processes and uses the set of quantifiable measures - Key Performance Indicators (KPI). Hereat, in order to raise the efficiency of logistics strategy implementation in construction companies, it is advisable to introduce this balanced scorecard system.

BSC ensures the integration of financial and nonfinancial indicators, taking into account the cause-and-effect relations between the resulting indicators and the factors under the influence of which they are formed. This allows for detailed monitoring of the enterprise activities in strategic focus, provides an opportunity to increase the efficiency and effectiveness of managerial decisions, offers the possibility of controlling the most important financial and nonfinancial performance indicators (KPI) that are of special

${ }^{2}$ Residential construction in Ukraine, 2010-2015. Statistical publication. Kyiv, 2016. -89 p. purpose for a construction company, and the degree of achievement of which is determined by its movement in accordance with the stated strategy. The KPI values reflect both the business performance as a whole and business processes that are considered separately, business units and personnel resources.

The Kaplan and Norton's system allows managers to represent business in four perspectives:

customer perspective;

internal process perspective;

learning and growth perspective;

financial perspective $[1,6,10,12,15]$.

BSC significantly widens the choices of strategic management making it more realistic. For this reason, the development of the formation and use of this conception in managerial systems of a construction company posesses great promising value.

BSC and KPI are modern tools for achieving strategic targets of both the company and its logistics system, as well as the effective implementation of the logistics strategy.

The following scheme of BSC and KPI system implementation for a construction company will allow to improve significantly the efficiency of both the development and the implementation of logistics strategy (Figure 1).

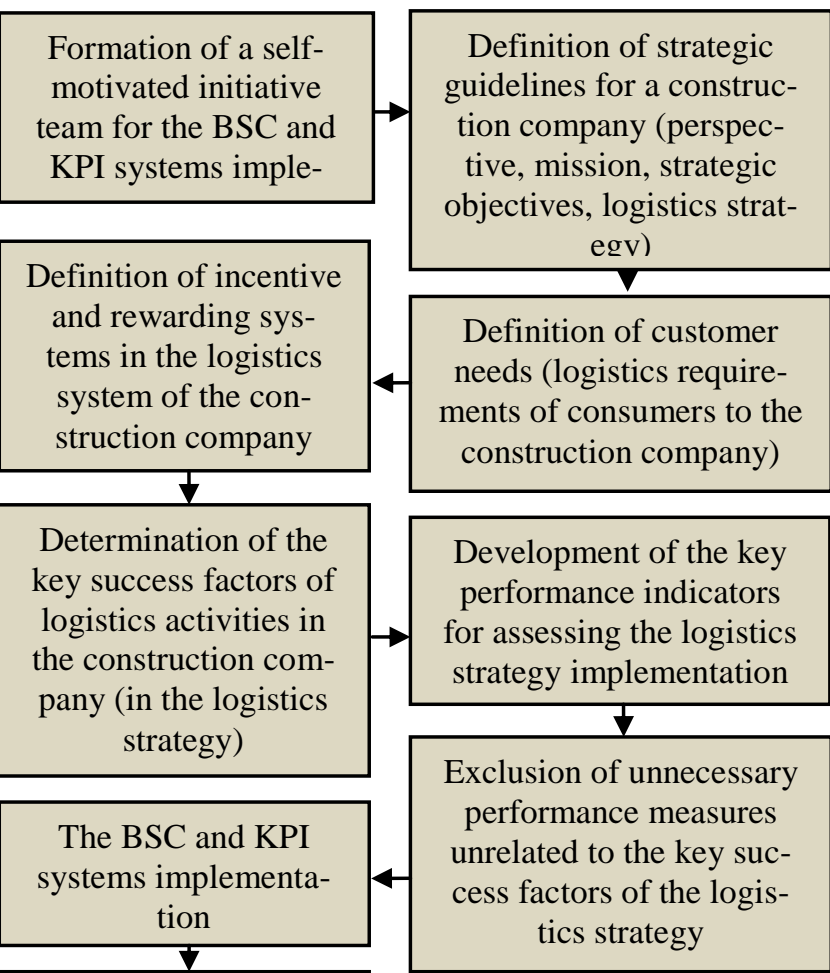

Implementation of the information system and the technologies

of indicators formation

Changes of incentive and rewarding systems in the logistics system of the construction company

Providing continuous improvement

Fig. 1: The mechanism of the BSC and KPI systems implementation for the logistics system of a construction company

In fact, by implementing the system of indicators without significant costs (only expenses on improving the information system and developing the scorecard) under an effective management of change system, we will receive a qualitative tool for assessing the effectiveness of implementing not only the logistics strategy of the construction company, but also its other strategic goals and objectives. In order to develop the KPI in accordance with the goals and objectives, required for the logistics strategy implementation, the construction company should use the rules and principles: the rule "10/80/10" - the company ought to have about 10 key measures of 
efficiency, up to 80 business performance indicators and 10 key performance indicators; the principle of manageability and the controllability concept; the principle of co-partnership; the principle of transferring the efforts to the privileged directions; the principle of process integration of performance evaluation, rendering of accounts assessment, productivization; the principle of coordinating between the indicators with the strategy.

After developing the key indicators system, focused on success factors, critical for a company, it is necessary to analyse the assessment system of logistics performance results and the rewards and incentives systems in order to bring them into line with the key indicators. If it is not done, then the motivation of managers will be carried out according to the old rules, which, in its turn, will have an impact on the quality of achieving strategic goals.

\subsection{Components of a Construction Company Logistics Strategy}

In order to estimate the implementation of logistics strategy in a construction company, we offer the following indicator sets: the general set of KPI for estimating the implementation of the enterprise logistics strategy;

specific sets of KPI for estimating the logistics strategy implementation in certain areas of logistics:

the supply area KPI or logistic support KPI;

the manufacturing KPI;

the distribution area KPI;

the KPI of logistics infrastructure systems (transport, warehouse, stocks, provisions, information, service) - fig. 2.

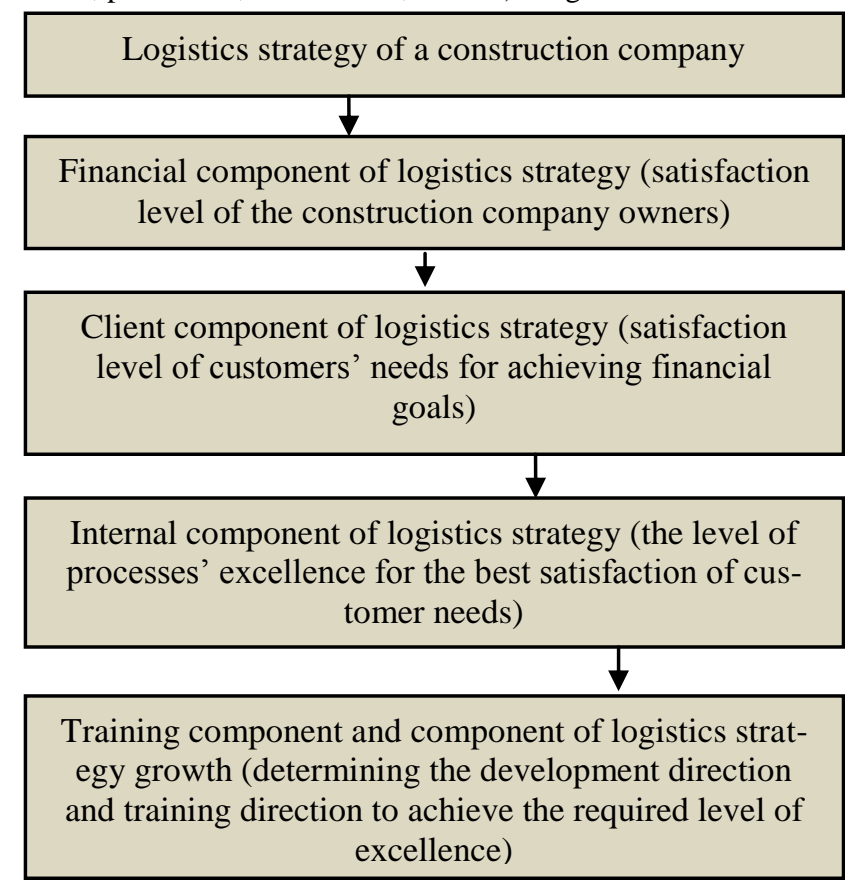

Fig. 2. Components of a construction company logistics strategy

Nonetheless, according to the Kaplan-Norton scorecard methodology, the establishment of the sales performance indicators system of logistics strategy should include four components that must be considered when establishing an indicators system. Among the general KPI for the enterprise it is expedient to use those that reflect logistics strategy direction: common logistics costs; the quality of logistics service; the duration of logistic cycles; productive efficiency; return on investment in logistics infrastructure. The system of key performance indicators of the effectiveness of evaluating the logistics strategy includes the indicators sets, the composition of which, starting with the client level, significantly depends on the direction of logistics strategy. So, for example, for logistics strategy of the construction company, targeted at logistics costs, the key performance indicators should be the indicators, oriented to logistics costs of the company, focused on this very direction and ought to include the following components (Table 3)
Table 3: KPI for estimating the implementation of the cost-oriented logistics strategy in a construction company

\begin{tabular}{|c|c|}
\hline Strategic Goal & Indicators \\
\hline \multicolumn{2}{|c|}{ Financial component of logistics strategy } \\
\hline $\begin{array}{l}\text { The growth of the enterprise earn- } \\
\text { ing power }\end{array}$ & $\begin{array}{l}\text { Return on assets, net operating } \\
\text { income after taxes deduction }\end{array}$ \\
\hline Increase in sales of products & $\begin{array}{l}\text { Income of an enterprise, working or } \\
\text { current assets }\end{array}$ \\
\hline Optimization of logistics costs & $\begin{array}{l}\text { Total logistics costs, specific logis- } \\
\text { tical costs }\end{array}$ \\
\hline \multicolumn{2}{|c|}{ Client component of logistics strategy } \\
\hline $\begin{array}{l}\text { Diminution in the final value of } \\
\text { products, works, services }\end{array}$ & The quantity traded \\
\hline $\begin{array}{l}\text { Providing optimization of the range } \\
\text { of products according to profit- } \\
\text { earning capacity }\end{array}$ & Profitability of sales \\
\hline $\begin{array}{l}\text { Diminution in the value of inter- } \\
\text { mediary services in prices of prod- } \\
\text { ucts, works and services }\end{array}$ & $\begin{array}{l}\text { Share of the cost of intermediary } \\
\text { services in the price of products, } \\
\text { works, services }\end{array}$ \\
\hline $\begin{array}{l}\text { Service activities at the minimum } \\
\text { required level }\end{array}$ & $\begin{array}{l}\text { Maintenance costs in relation to } \\
\text { sales volumes }\end{array}$ \\
\hline \multicolumn{2}{|c|}{ Internal component of logistics strategy } \\
\hline $\begin{array}{l}\text { Optimization of the raw materials } \\
\text { supply system }\end{array}$ & $\begin{array}{l}\text { Outlay for purchase, the share of } \\
\text { raw materials in the products value }\end{array}$ \\
\hline $\begin{array}{l}\text { Optimization of services according } \\
\text { to the "profits-expenses" scheme }\end{array}$ & $\begin{array}{l}\text { Revenue with reference to cost-to- } \\
\text { service expenses }\end{array}$ \\
\hline $\begin{array}{l}\text { Expenditure management system } \\
\text { implementation or development }\end{array}$ & Rate of consumption \\
\hline $\begin{array}{l}\text { Reduction of logistics operations } \\
\text { duration }\end{array}$ & Operational and logistics cycles \\
\hline the BSC and KPI implementation & $\begin{array}{l}\text { The level of strategic goals } \\
\text { achievement }\end{array}$ \\
\hline $\begin{array}{l}\text { Strategic logistics management } \\
\text { implementation }\end{array}$ & $\begin{array}{l}\text { The level of logistics strategic } \\
\text { goals achievement }\end{array}$ \\
\hline $\begin{array}{l}\text { Mastering of new technologies and } \\
\text { equipment }\end{array}$ & Return on investment in innovation \\
\hline $\begin{array}{l}\text { Formation of the distribution sys- } \\
\text { tem, most appropriate in expenses }\end{array}$ & $\begin{array}{l}\text { Distribution expenses in relation to } \\
\text { the volume of sales }\end{array}$ \\
\hline \multicolumn{2}{|c|}{ Training component and component of logistics strategy growth } \\
\hline $\begin{array}{l}\text { Implementation of incentive system } \\
\text { for costs }\end{array}$ & $\begin{array}{l}\text { The share of the cost savings } \\
\text { amount in the total amount of ex- } \\
\text { penses }\end{array}$ \\
\hline $\begin{array}{l}\text { Improvement of personnel running } \\
\text { efficiency according to operations }\end{array}$ & $\begin{array}{l}\text { Productive efficiency of the per- } \\
\text { sonnel }\end{array}$ \\
\hline $\begin{array}{l}\text { Creation of corporate culture aimed } \\
\text { at changes }\end{array}$ & $\begin{array}{l}\text { Actual realization time of changes } \\
\text { in relation to the planned time }\end{array}$ \\
\hline $\begin{array}{l}\text { Staff incentives in order to facili- } \\
\text { tate innovation development }\end{array}$ & $\begin{array}{l}\text { The number of innovations per one } \\
\text { worker }\end{array}$ \\
\hline
\end{tabular}

The offered indicators should be included in the information system of a construction company. The process of their introduction has to be implemented stagewise - at first, the most important indicators are introduced, and in due course - all the rest ones (it allows to avoid the information system overloading).

\section{Conclusion}

The process of forming a logistics strategy is a rather complex process, especially for construction companies. The proposed guidepost indicators provide an opportunity to insure the process of logistic activity based on modern approaches and procedures in accordance with the chosen logistics strategy of the construction company.

Benefits of using a balanced scorecard system of indicators: fundamental understanding of business in all interconnections of internal and external processes;

strategic business orientation of all business units and employees; stepping up the rate of growth of strategic goals achievement; purposeful focused allocation of all resources;

performance evaluation of managerial decisions within the framework of the construction company's strategy;

understanding by all the employees of the construction company's strategic goals and of their personal goals upon reaching them; improvement of professional engagement and interaction between employees and business units; 
obtaining key business information in an understandable, generalized, non-random manner;

personal responsibility of the managerial personnel and average executives for the performance of indicators, assigned to them; increase in staff motivation due to clear personal goals and objectives.

Consequently, the key performance indicators system lays the necessary groundwork for assessing the logistics strategy of the construction company and increases the information support level of logistics solutions.

\section{References}

[1] Bochko O. Y. \& Rusanovska O. A., Intehratsiia ryzyk menedzhmentu ta kontrolinhu lohistychnoi diialnosti pidpryiemstva, Mizhnarodnyi naukovyi zhurnal «Internauka». Seriia: «Ekonomichni nauky», № 6(6), (2017), pp. 52-55.

[2] Budnikevych I. \& Cherdantseva I., Formuvannia konkurentnykh stratehii rozvytku pidpryiemstv rozdribnoi torhivli v instytutsionalnomu seredovyshchi, Skhid, № 5(145) veresen-zhovten, (2016), pp. $5-10$.

[3] Kharynovych-Yavorska Diana O., Application of neural technology for prediction competitive strategy of trade enterprises, Mizhnarodnyi naukovyi zhurnal «Internauka». Seriia: «Ekonomichni nauky», № 2(2), (2017), pp. 24-27.

[4] Khomchuk M. V., Rol ta mistse lohistychnoho audytu v protsesi formuvannia lohistychnoi stratehii pidpryiemstva optovoi torhivli, Mizhnarodnyi naukovyi zhurnal «Internauka». Seriia: «Ekonomichni nauky», № 7(7), (2017), pp. 57-64.

[5] Kozenkov D. Y. \& Faizova S. O., Adaptatsiia BSC do praktyky upravlinnia metalurhiinoho pidpryiemstva, Visnyk Natsionalnoho universytetu «Lvivska politekhnika», № 722, (2012), pp. 362-368.

[6] Kutsyk P. \& Ostapyuk N., Organization of operational and strategic controlling in integrated accounting system, Tekhnolohichnyi audyt ta rezervy vyrobnytstva, № 3/4(35), (2017), pp. 24-29.

[7] Maiorova I.M., Suchasna marketynhovo-lohistychna kontseptsiia vyrobnychoho pidpryiemstva, "Ekonomichnyi visnyk NTUU "KPI", № 89, (2014), available online: http:// economy.kpi.ua/uk/node/757, last visit: 19.04.2018.

[8] Mamonov K.A., Prunenko D.O. \& Uhodnikova O.I., Formuvannia systemy informatsiino-analitychnoho zabezpechennia stratehii upravlinnia intelektualnym kapitalom budivelnykh pidpryiemstv, Visnyk ekonomiky transportu i promyslovosti, № 60, (2017), pp. 153-163.

[9] Mints A. Y., Modelirovanie tsenoobrazovaniya na ryinke jiloy nedvijimosti metodami sistemnoy dinamiki, Tekhnolohichnyi audyt ta rezervy vyrobnytstva, № 5/4(31), (2016), pp. 39-45.

[10] Raikovska I.T., Model suchasnoho stratehichnoho upravlinnia pidpryiemstvom: zmist i komponenty, Visnyk ZhDTU. Seriia: Ekonomichni nauky, № 3(73), (2015), pp. 106-117.

[11] Rudkivskyi O.A., Lohistychna stratehiia molokopererobnoho pidpryiemstva: problematyka vyboru ta realizatsii, Visnyk ZhDTU. Seriia: Ekonomichni nauky, № 4(70), (2014), pp. 226-231.

[12] Rusinova O., Model systemy upravlinnia zabezpechenniam rozvytku promyslovoho pidpryiemstva, Skhid, № 3(149) travencherven, (2017), pp. 16-20.

[13] Synytsia L.V., Problemy vyboru priorytetnoho napriamku stratehichnoho rozvytku pidpryiemstva, Visnyk ekonomiky transportu i promyslovosti, № 58, (2017), pp. 187-197.

[14] Shevchuk O.A., Ekzohenni faktory vplyvu na stratehichni oriientyry rozvytku vitchyznianykh pidpryiemstv, "Ekonomichnyi visnyk NTUU "KPI", № 12, (2015), available online: http://ev.fmm.kpi.ua/article/view/45523/41699, last visit: 19.04.2018.

[15] Tarasiuk H., Rudkivskyi O. \& Pohaidak O. Kliuchovi pokaznyky efektyvnosti ta otsinka lohistychnoi stratehii pidpryiemstva, Sotsialno-ekonomichni problemy $i$ derzhava, Vyp. 2(9), (2013), pp. 223-231. 